\title{
Employment at Commercial Service Airports in the USA: Survey Results
}

\author{
David A. NewMyer, Karen Korir, and Hitesh Mehta \\ Southern Illinois University Carbondale
}

\begin{abstract}
The purpose of this research was to ascertain the size and scope of employment at US commercial service airports (CSAs) by: (1) determining the number of full-time and part-time employees employed directly by the operating entities of CSAs; (2) determining the total number of employees employed at these CSAs, including those working not only for airport operators, but also for airport tenants; and (3) comparing the findings to figures found in literature. A literature review was conducted, and all 510 US CSAs were contacted by phone and/or mail and asked to complete a five-question survey. A response rate of $95.1 \%(n=485)$ was obtained. Survey results indicate there are 45,067 full-time and 2,558 part-time employees directly employed by commercial service airport operators. Additionally, when airport tenants are taken into account, survey results indicate 1,154,660 people are employed at CSAs. This study provides more detailed airport employment data than that which is available in current sources, such as the US Department of Labor. It also provides a larger sample size and more comprehensive analysis than previous recent studies, such as the one reported in the November/December issue of Airport Magazine.
\end{abstract}

\section{INTRODUCTION AND PURPOSE}

There are 19,576 landing sites in the United States as of January 2004 (Federal Aviation Administration [FAA], Report to Congress, p. 1). However, only 510 of these airports are classified as commercial service airports (CSAs). CSAs are defined in the Federal Aviation Administration's (FAA) National Plan of Integrated Airport Systems (NPIAS) as "public airports receiving scheduled passenger service and having 2,500 or more enplaned passengers per year" (FAA, Report to Congress, p. 5). These CSAs are economic engines for their surrounding communities.

Because industry-specific employment data can be used to gauge the well-being of any given industry, it is important to remain up-to-date with employment numbers and trends. The total impact of civil aviation on the US economy exceeds $\$ 900$ billion annually, which represents approximately $9 \%$ of the nation's gross domestic product (Dri-Wefa, 2002, p.4). CSAs are a vital part of the aviation industry; therefore, tracking employment at these airports is one way to judge the state of the industry. However, a complete data set regarding employment at individual CSAs could not be found in the extant literature. Because an extensive data set regarding the number of employees employed directly by operating entities and by tenants of individual
CSAs is not available on a nationwide basis, further study is warranted. Therefore the purposes of this study are:

1. To conduct a literature review of sources available on airport employment to provide a more complete understanding of the data currently available related to CSA employment.

2. To conduct a survey of the size and scope of employment at CSAs by:

- determining the total number of employees directly employed by operating entities of CSAs.

- determining the total number of employees employed at these CSAs, including those working not only for airport operators, but also for airport tenants such as airlines, concessionaires, and freight forwarders.

\section{Definitions}

Throughout this report, the following definitions were used:

1. Commercial service airport - "Public airports receiving scheduled passenger service and having 2,500 or more enplaned passengers per year" (FAA, Report to Congress, p. 5)

2. Enplaned passengers - See enplanements 
3. Enplanements - Paid passenger departures or "boardings" (FAA, Report to Congress, p. 5). There were $650,808,785$ enplanements in the U. S. in Calendar Year 2003. (United States Department of Transportation, Bureau of Transportation Statistics, n. d.)

4. Large hub airport - "Airports that each account for at least one percent of total US passenger enplanements" (FAA, Report to Congress, p. 7)

5. Medium hub airport - "Airports that each account for between 0.25 percent and one percent of the total passenger enplanements" (FAA, Report to Congress, p. 7)

6. Non-hub primary airport - "Commercial service airports that enplane less than 0.05 percent of all commercial passenger enplanements but more than 10,000 annual enplanements" (FAA, Report to Congress, p. 7)

7. Non-primary commercial service airport - "Commercial service airports that have from 2,500 to 10,000 annual passenger enplanements" (FAA, Report to Congress, p. 7)

8. NPIAS - National Plan of Integrated Airport Systems (FAA, Report to Congress, p. v)

9. Small hub airport - "Airports that enplane 0.05 percent to 0.25 percent of the total passenger enplanements" (FAA, Report to Congress, p. 6)

10. General aviation airport "Communities that do not receive scheduled commercial service or that do not meet the criteria for classification as a commercial service airport may be included in the NPIAS as sites for general aviation airports...." (FAA, Report to Congress, p. 8)

\section{LITERATURE REVIEW}

Employment at CSAs is discussed in various sources. Among them are federal and state government documents, trade journals, and airport Web sites. These sources are further classified as:
- documents that provide individual airport operating entity employment figures.

- documents that provide total on-airport employment figures.

- national studies that provide broad-based airport employment statistics.

\section{Literature Reporting Employment by Airport Operating Entity}

Sources that provide CSA operating entity employment data on an airport-by-airport basis include state and local economic impact studies and individual airport Web sites. Some states have compiled data regarding CSA operating entity employment in state aviation studies. A statewide airport analysis completed for the North Carolina Department of Transportation, for example, reported both full and part-time employees employed by the airport operator (Hartgen, Bondurant, Dakai, Morris, \& Stuart, 1997); as is the case with many such studies, this report discussed not only CSAs, but also general aviation airports.

In addition, economic impact statements conducted for individual airports may include CSA operating entity employee counts. An economic impact report summary carried out by San Jose International Airport revealed that 194 people were employed by the airport's administration (San Jose International Airport, 1986, p. 3).

Furthermore, several CSAs list operating entity employment figures on their respective Web sites. These statistics are often found on Web pages titled "Airport Facts," "Fast Facts," or "About the Airport." For instance, Lambert St. Louis International Airport's Web site stated that the airport employs 550 City of St. Louis employees (General Information about Lambert, p. 6). Other Web sites, such as that of Baltimore/Washington International Airport, offered operating entity employment figures for the number of allocated positions as well as the number of filled positions (General Statistics BWI Facts and Figures, Employment section). It is not only the large hub airports that list employment information; even smaller airports, like Gallatin Field in Bozeman, Montana, provide their operating entity employment figure 
(Gallatin Field Airport Fact Sheet, 2004, Employment section).

Because of the dynamic nature of Web pages, it is straightforward to obtain up-to-date airport employment figures, provided that CSAs update their Web pages on a regular basis. However, a significant number of CSAs do not provide operating entity employment information on their Web pages, and some do not even have a Web site. Another limitation is that CSAs rarely have the need to break down operating entity employees in terms of full-time and part-time employees on their Web sites, so those aspects of each airport's employment remain unknown.

\section{Literature Reporting Total On-Airport Employment}

Numerous sources, such as state and local economic impact studies and airport Web sites, give an account of total on-airport employment. Note that these sources are identical to those that report employment by CSA operating entity, as described above. Indeed, a few of these sources provide both CSA operating entity employment and total on-airport employment figures. However, documents containing total on-airport employment numbers are more commonly found in literature.

Many of the state publications that report total on-airport employment take the form of aviation or airport economic impact studies. Some sources show total on-airport employment on airport-by-airport basis, whereas others only provide aggregates. For example, the Illinois Department of Transportation's Division of Aeronautics released a study in 1996 in which 119 CSAs and non-CSAs in Illinois were surveyed for various data, including employment figures. In this report, total onairport employment, in terms both of full-time and part-time employees, was reported on an airport-by-airport basis for the majority of Illinois CSAs (Jamison, 1996). Similar airportby-airport economic impact reports that showed CSA on-airport employment were conducted for Florida (Wilbur Smith Associates, 2000) and Washington (Washington State Department of Transportation Aviation Division).
On the other hand, various state publications list total on-airport employment without specifying employment figures for individual airports. A pamphlet issued by the New Mexico Department of Transportation's Aviation Division stated that there were 4,580 full-time on-airport jobs at New Mexico CSAs in 2002 (New Mexico Department of Transportation Aviation Division, 2003, Commercial Aviation section). Vermont's Agency of Transportation published a similar document, stating there are a total of 8,500 employees at its two CSAs (Vermont Agency of Transportation, Commercial and General Aviation Section). Similar documents are available from Arizona (Arizona Department of Transportation Aeronautics Division, 2004); Georgia (Georgia Department of Transportation, 2004); and Iowa (Swenson \& Eathington, 2000).

Yet another category of state documents that provide total on-airport employment are those that include employment based on total economic impacts rather than just direct economic impacts; these employment figures incorporate not only employment segments supporting aviation activity (total on-airport employment), but also employment due to indirect impacts and economic multiplier effects, as spending re-circulates within the airport's region. Thus, these CSA employment numbers take into account a broader spectrum of employees and are much larger than the ones mentioned previously. For example, Colorado's CSAs were reported to produce a total impact of 260,803 jobs on the Colorado economy in 2003 (Colorado Department of Transportation Aeronautics Division, 2003, p. 6). Studies completed for Missouri (Missouri Department of Transportation) and Texas (Texas Department of Transportation) reported CSA employment numbers in a similar fashion.

Additionally, some CSAs individually commission economic impact studies, which often include total on-airport employment figures. A 2003 study performed for Wichita's Mid-Continent International airport, for instance, stated that a total of 15, 006 existed at the airport (Harrah, Gallagher, \& Townsend, 2003).

The final group of sources that discuss total on-airport employment are the respective Web 
sites of CSAs. Again, as for operating entity employee numbers, total on-airport employment figures are usually found on Web pages entitled "Airport Facts," "Fast Facts," or "About the Airport." Newark Liberty International Airport's Web site, for example, states that "over 24,000 people are employed at the airport" (Port Authority of New York and New Jersey, Employment and Economic Impact section). Many other airports list total on-airport employment numbers on their Web sites, such as Palm Springs International Airport, Little Rock National Airport, and Cincinnati/Northern Kentucky International Airport.

\section{Overall National Studies}

Some publications describe CSA employment on a broader level; they do not break down employment on an airport-by-airport basis or even by state. Rather, they provide aggregate data related to CSA employment. These sources include federal documents, national studies, and national trade journals.

One of the most comprehensive sources of employment statistics is maintained by the United States Department of Labor's Bureau of Labor Statistics (BLS). The BLS tracks employment related to airports in two categories: airport operations (North American Industry Classification System Code 48811) and airport operations specialists (Standard Occupational Classification Code 53-2022). However, neither of these sources provides CSA-specific data. For example, the North American Industry Classification System Code $48811 \quad$ (NAICS 48811) "comprises establishments primarily engaged in (1) operating international, national, or civil airports or public flying fields or (2) supporting airport operations (except special food service contractors), such as rental of hangar space, air traffic control services, baggage handling services, and cargo handling services" (United States Census Bureau, p. 1). In 2003, the BLS reported a total of 112,923 employees working for federal, state, and local government agencies and private entities in the NAICS 48811 classification (United States Bureau of Labor Statistics [BLS], Quarterly Census of Employment and Wages). The problem with this data, however, is that it not only fails to specify the number of employees employed directly by CSA operating entities, but it also includes employment at non-CSAs, which distorts the employment information. Even if the BLS kept track specifically of CSA operating entity employment for their internal use, this data is not available to the public, since the BLS does not release "microdata" in order to protect the confidentiality of respondents (R. Stephens, personal communication, March 2, 2005).

Furthermore, the BLS Standard Occupational Code 53-2022 estimated that in November 2003, there were 4,670 people employed as airfield operations specialists, defined as those who "ensure the safe takeoff and landing of commercial and military aircraft" (BLS, Occupational Employment and Wages, p. 1). Again, these employees may or may not be employed by CSAs, and because airfield operations specialists are not the only employees employed by operating entities of CSAs, this number is an underestimate of CSA operating entity employment. Therefore, the data provided by the BLS is either too broad or too narrow, and it does not adequately reflect CSA employment, which renders it not applicable to this study.

Next, national aviation studies also discuss airport employment in a general manner. For example, a study carried out by Wilbur Smith Associates entitled The Economic Impact of Civil Aviation on the U.S. Economy showed that aviation had a direct impact of 2,165,728 jobs and an indirect impact of 5,632,945 jobs in 1993 (1995, p. 5). The combined impacts total $7,798,673$ jobs, which accounted for approximately $88.2 \%$ percent of 1993 's total civil aviation-related jobs (Wilbur Smith Associates, p. 5). Note that these figures take into account an economic multiplier effect, as described earlier.

In addition, a study conducted by Airports Council International-North America (ACI-NA) in 2002 regarding the impact US airports have on local regions found that there are 1.9 million on-airport jobs at US airports and 4.8 million jobs created in local communities, which result in $\$ 190$ billion in earnings (Airports Council International-North America [ACI-NA], 2002, p. 1). The study also projected that U.S airport 
related employment will be 9.9 million in 2013 (ACI-NA, p. 2). This growth is projected to correspond with the increase in outputs and earnings of the airports (ACI-NA, p. 3). The study showed the significance commercial service has on airport employment. For example, it highlights the example of Baltimore/Washington International Airport (BWI), where 12,030 jobs result directly from airport activity, totaling $\$ 358$ million in wages and salaries in 2000; of the total jobs, 10,465 jobs, or $87 \%$, were generated by commercial service activities (ACI-NA, p. 10). At a smaller airport-Blue Grass Airport in Lexington, Kentucky-commercial service activities also accounted for the majority (57\%) of the 1,760 jobs it contributed to the local economy in 2001 (ACI-NA, p. 11).

The Airports Council International's Fifth Annual Economic Survey stated that in North America, 43,000 people are directly employed by airport operators and that there are 1,106,000 jobs on airport sites ("That Was Then...," 2001, p. 42) Note that this number includes CSAs outside of the US as well. Similarly, in September 2004, the International Civil Aviation Organization provided somewhat similar numbers in its Thirty-Fifth Assembly Session Economic Commission Working Paper presented by the ACI. It estimated that in North America, 42,000 employees are directly employed by airport operators and 2 million jobs are at on-airport sites (International Civil Aviation Organization, 2004).

Moreover, trade journals contain various articles regarding CSA employment. For instance, two recent articles published in AAAE's Airport Magazine described CSA employment by hub category. Page (2004, p. 24) reported an average number of CSA operating entity employees at large, medium, small, and non-hub CSAs at 606, 276, 81, and 27 employees, respectively. Although this survey provides recent data regarding CSA operating entity employees, it does not list data on an airport-by-airport basis. Furthermore, the survey was based on only 188 responses (Page, 2004). The January/February 2005 issue of Airport Magazine showed that airport jobs are dependent on the size of the airport (Page, 2005). That study provided equations for estimating the optimum number of airport staff. While the relationship between airport size and number of employees may be logically obvious, this study helped explain the variance in the employment figures at different airports.

Moreover, prior studies regarding aviation employment reported approximately 2.1 million aviation employees in the US (NewMyer, Kaps, \& Sharp, 1997; NewMyer \& Owen, 2003). However, these studies were generic in nature, as they focused on obtaining an overall US aviation industry employment estimate. The 2003 study by NewMyer and Owen reported a total of 37,088 persons employed directly by the operating entities of the 100 busiest CSAs; however, the remaining $400 \mathrm{CSAs}$ - a vital segment of the nation's airport system-were excluded in that survey.

\section{Literature Review Conclusion}

This study was warranted because of several limitations with existing CSA employment data. First and foremost, a complete set of data regarding the number of people employed by CSA operating entities - and by airport tenants - is not available on an airport-by-airport basis. Many inconsistencies exist within the existing literature. For example, in economic impact studies, some state documents provide airport-by-airport-breakdowns of both CSA operating entity employment and total on-airport employment, whereas others only provide total on-airport employment. Similarly, some airport Web sites list employees employed by the operating entity, others list total on-airport employees, and still others do not provide any employment count whatsoever.

Next, the data available in literature was not collected at the same time, so it is difficult to compare data sets, and one cannot expect to arrive at accurate conclusions about CSA employment trends. Furthermore, much of the data is no longer current. National tragedies such as the terrorist attacks of September 11, 2001, and local events such as the closing of a major regional business can affect employment at CSAs, so it is imperative that current data be used.

Another issue in using the data in literature to reach conclusions about CSA employment is 
that the methods of data collection differed from study to study. Some studies provided employment estimates, while others extrapolated data based on trends. Some studies provided CSA employment numbers based on the total economic impact of the airport, whereas others merely provided direct airport employment.

Thus, after reviewing literature, it was found that no detailed and same-date CSA employment data was available in an airport-by-airport method. Because the employment numbers were inconsistent in their methods and dates of collection, a specific number of CSA operating entity employees and total on-airport employees could not be firmly established.

\section{METHODOLOGY}

In order to have a systematic approach to collecting and recording data, the study used the FAA's 2002 enplanement data as its primary source of CSAs (FAA, Passenger boardings). This provided the study with a set of 509 CSAs ranked by enplanements, as well as other information - such as location identities and hub classification which would be useful in analyzing the data collected. To obtain a more recent data set, the FAA 2002 enplanement ranking was compared to the CSAs included in the 2005-2009 NPIAS (FAA, Report to Congress). All the CSAs in the 2002 enplanement ranking were included in the NPIAS dataset with the exception of Charlevoix Municipal Airport (CVX). CVX was therefore added to the enplanement list, resulting in a total of 510 CSAs contacted for this study. However, because CVX was not a CSA in 2002, it was not included in any of the data analyses that dealt with enplanement data.

The collection of data for this research entailed contacting airport personnel at CSAs. Therefore, as is required by research policy at Southern Illinois University Carbondale (SIUC), an approval to conduct research involving human subjects was obtained from the SIUC Human Subjects Committee in 2004, prior to beginning the study. An extension of the approval was granted on October 14, 2004, effective through November 21, 2005.

The data collection was undertaken between September 30, 2004 and March 30, 2005.
During this period, there were two approaches to the collection of data. First, the study started out with a phone survey. Airport personnel were asked questions from the study's questionnaire (see Appendix A). This was conducted for about a month, during which approximately 125 CSAs were contacted, most of which were called more than once. Approximately 50 responded. Due to the low response rate, expense, and time consumed, the researchers opted to switch to a mail survey in order to collect the data needed.

After obtaining contact names and addresses from sources such as airport Web sites, the AAAE print and online directories (American Association of Airport Executives, 2003), and the World Aviation Directory \& Aerospace Database (Jackman, 2004), the surveys were mailed. Due to the time, it took to gather contact information of appropriate airport personnel, the surveys in the first mailing were sent in batches during the week of October 18, 2004. However, the first mailing did not include any noncontinental US CSAs because contact information was not yet in hand. These CSAs were located in Hawaii, Alaska, Puerto Rico, Guam, American Samoa, and the Northern Mariana Islands, and surveys for these CSAs were sent as soon as contact information was obtained. Depending on contact information available, surveys were addressed to a variety of airport personnel, such as airport managers, airport directors, human resource managers, and public relations managers. Additionally, because some operating entities were known to run multiple CSAs - such as the majority of Alaskan CSAs-only one person may have been contacted to provide employment data for those CSAs.

As responses were received, the data set was updated. A second mailing was completed during the week of December 15, 2004. A third mailing was sent during the week of January 21 , 2005 and a final mailing sent during the week of February 7, 2005. These mail surveys gave CSAs the option to respond by mail (return envelopes were enclosed with each survey), fax, e-mail, or phone. However, majority of the responses were received by mail. Representatives at nine airports responded by fax and data for 78 airports was received by email. (Note that 71 of these e-mail responses 
were obtained from one source in Alaska.) Despite the study's reliance on mail surveys, phone surveys were not completely abandoned.

Phone surveys were continued throughout the mailing process, especially to follow-up on mail responses that were not clear. Furthermore, after all mailings were completed, an additional 34 CSAs responded to the survey by phone.

Data collection was completed during the week of April 1, 2005. The study had an extremely robust response rate of $95.1 \%$. As shown in Figure 1, out of the 510 total CSAs surveyed, 485 responses were received and only 25 CSAs (4.9\%) did not respond.

It is also important to note that all of the top 100 airports ranked by 2002 enplanements responded to the survey, as shown in Figure 2. Only two airports ranked within the top 200 CSAs did not respond to the survey. The remaining 23 airports that did not respond were among airports ranked lower than position 200 based on enplanements.

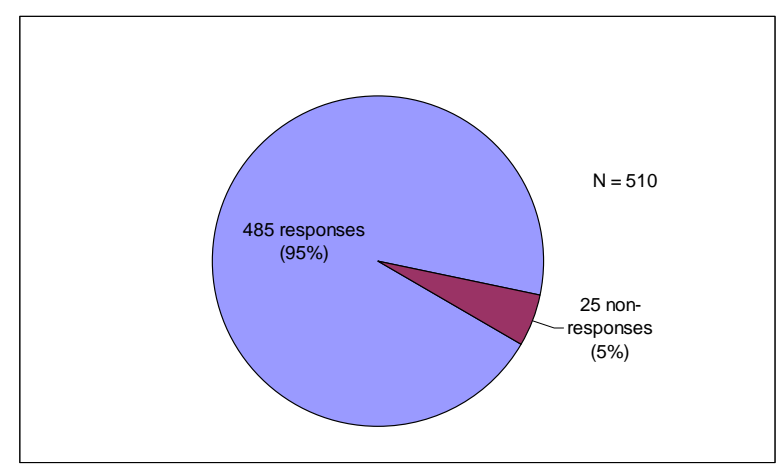

Figure 1. Overall response rate: operating entity employment

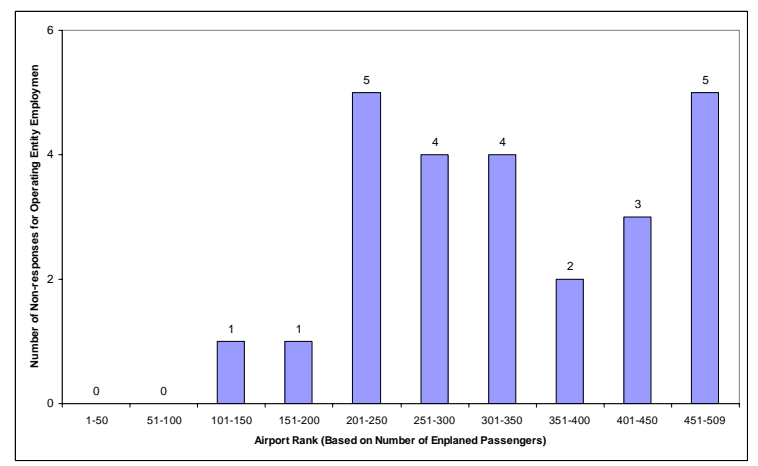

Figure 2. Distribution of non-responses for operating entity employment

\section{Assumptions and Guidelines Used in Analysis}

In recording the responses received from CSAs, the following guidelines were used in order to maintain a systematic study:

1. Unless otherwise noted by the respondent, the employment statistics provided were assumed to be current and accurate as of the day the survey was completed.

2. If a range of employment statistics was given instead of a single figure, the low employment estimate was used.

3. If multiple surveys were received from any given CSA, the survey completed by the person of higher organizational rank was used.

4. Contract positions were included in operating entity employment numbers.

5. Seasonal employment numbers were combined with part-time employment numbers to make a category of part-time and seasonal operating entity employees.

6. When recording the responses for the type of operating entity in the "other" category, similar responses were batched together. For example, aviation commission and airport commission were all reported as airport commissions.

7. CSAs opting to have their employment numbers remain confidential were noted, and their numbers will not be disclosed but will be included in statistical analyses.

\section{Limitations}

Despite the wide representation this study has due to its high response rate, the study also has its limitations, as is expected with any study. Below are some of these limitations.

1. The data reported as survey results are self-reported data and can not be independently verified for each airport.

2. Because the survey data were collected over a six month period of time spanning the end of 2004 and early 2005, no one date can be attributed to the results. 
3. Question 5 in the survey (See Appendix A) did not specifically instruct the respondent to include or not data reported in Question 4. Therefore, the reported overall airport employment figures may or may not include airport operating entity employment data in a consistent fashion.

4. Though updated by the NPIAS 2005-2009 list, the 2002 FAA enplanement ranking list is the base of this study. When the study was started, this was the most recent enplanement data available.

5. The study may have understated the results because:

A. Some CSAs did not include their total on-airport employment numbers. Out of the top 100 airports ranked by enplanements, eight did not provide their total employment figure. This includes San Antonio International, TX (ranked 48); Kahului, HI (56), Tulsa International, OK (71); A.B. Won Pat Guam International, GU (75); Lihue, HI (78), Hilo International, HI (92); Pensacola Regional, FL (96); and Harrisburg International, PA (97). There were also twenty three other CSAs ranked between 100 and 509 that did not provide total on-airport employment.

B. Eight airports reported being seasonal airports; their employment numbers fluctuate and may increase significantly during peak seasons. Half of these seasonal airports are located in Colorado.

C. Seven airports reported their employment numbers using full-time equivalents rather than an actual employee head count.

D. Ten airports reported employment statistics from previous years.

E. Five airports listed on the FAA 2002 enplanement ranking list no longer have commercial service. These airports are: Kileen-Fort Hood Regional, TX (ranked 208); Ellington Field, TX (265); Groton-New London, CT (411); Los Alamos, NM (440); and Smith Reynolds, NC (498).

\section{SURVEY RESULTS AND ANALYSIS}

\section{Overall Results}

Respondents were asked to provide the number of employees employed by the airport operating entity, and of the $95.1 \%$ who responded to the survey question, a total of 47,625 employees are reported to be employed by operating entities of CSAs. Of this total, $45,067(94.6 \%)$ are full-time employees and $2,558(5.4 \%)$ are part-time employees. The top 20 CSAs in terms of airport operating entity employment are shown in Figure 3. As noted in the figure, there are four airports that employ 1600 or more full and part time employees: Los Angeles International (LAX), Miami International (MIA), Dallas/Fort Worth International (DFW) and Chicago O'Hare International (ORD). The LAX total of 2,460 employees far and away is the leading number of operating entity employees at any one airport. Note that the top 20 airports ranking by operating entity employees employ a total of 20,833 employees, or $43.7 \%$ of the total reported by all respondents.

Based on an $89.2 \%$ response rate for the survey question regarding the total number of employees working at the airport (on-airport employees), there are 1,154,660 employees reported to be working at CSAs. This number includes businesses at the airport, such as airlines, concessionaires, fixed base operators (FBO's) and freight forwarders. Figure 4 shows the top 20 airports ranked by their reported onairport employment. Three of the reporting airports indicated that they had 40,000 or more on-airport employees each. These airports were Hartsfield-Jackson Atlanta International Airport (ATL) at 48,000, Chicago O'Hare International Airport (ORD) at 45,000, and Dallas/Fort Worth International Airport (DFW) at 40,000. The top 20 airports listed in Figure 4 employ 557,982 or $48.3 \%$ of the total reported on-airport employees. See Appendix B for additional data regarding employment at various categories of top 20 airports. 


\begin{tabular}{|c|c|c|c|c|c|c|}
\hline & Airport Name & Operating Entity & $\begin{array}{c}\text { Total Operating Entity } \\
\text { Employees }\end{array}$ & $\begin{array}{l}\text { Full-time Operating } \\
\text { Entity Employees }\end{array}$ & $\begin{array}{l}\text { Part-time Operating } \\
\text { Entity Employees }\end{array}$ & $\begin{array}{c}\text { Total Reported } \\
\text { Employees Working at } \\
\text { Airport }\end{array}$ \\
\hline 1 & Los Angeles International & City & \begin{tabular}{|c|}
2,460 \\
\end{tabular} & 2,250 & 210 & 37,500 \\
\hline 2 & Miami International & \begin{tabular}{|l|} 
County \\
\end{tabular} & 1,692 & 1,648 & 44 & 37,700 \\
\hline 3 & Dallas / Fort Worth International & Airport District or Authority & 1,608 & 1,600 & 8 & 40,000 \\
\hline 4 & Chicago O'Hare International & City & 1,600 & 1,600 & 0 & 45,000 \\
\hline 5 & San Francisco International & \begin{tabular}{|l|} 
Other: Airport commission \\
\end{tabular} & 1,277 & 1,183 & 94 & 23,304 \\
\hline 6 & Ronald Reagan Washington National & Airport District or Authority & 1,147 & 1,116 & 31 & 9,735 \\
\hline 7 & General Edward Lawrence Logan International & Port District or Authority & 1,124 & 1,093 & 31 & 15,000 \\
\hline 8 & McCarran International & County & 1,120 & 1,100 & 20 & 15,120 \\
\hline 9 & George Bush Intercontinental & City & 1,000 & 900 & 100 & 30,000 \\
\hline 10 & Denver International & City & 950 & 950 & 0 & 25,000 \\
\hline 11 & John F. Kennedy International & Port District or Authority & 800 & 800 & 0 & 35,000 \\
\hline 12 & Seattle - Tacoma International & Port District or Authority & 800 & 723 & 77 & 19,017 \\
\hline 13 & Philadelphia International & City & 782 & 754 & 28 & 22,000 \\
\hline 14 & Detroit Metropolitan Wayne County & Airport District or Authority & 718 & 706 & 12 & 18,171 \\
\hline 15 & Hartsfield-Jackson Atlanta International & City & 700 & 700 & 0 & 48,000 \\
\hline 16 & Orlando International & Airport District or Authority & 665 & 618 & 47 & 16,600 \\
\hline 17 & Phoenix Sky Harbor International & City & 657 & 654 & 3 & 31,000 \\
\hline 18 & Washington Dulles International & Airport District or Authority & 585 & 554 & 31 & 18,504 \\
\hline 19 & Salt Lake City International & City & 584 & 576 & 8 & 14,000 \\
\hline 20 & Tampa International & \begin{tabular}{|l} 
Airport District or Authority \\
\end{tabular} & 564 & 564 & 0 & 7,000 \\
\hline & TOTALS & & 20,833 & 20,089 & 744 & 507,651 \\
\hline
\end{tabular}

Figure 3. Top 20 airports based on total operating entity employment

\begin{tabular}{|c|c|c|c|c|c|c|}
\hline & Airport Name & $\begin{array}{c}\text { Total Reported } \\
\text { Employees Working at } \\
\text { Airport }\end{array}$ & $\begin{array}{l}\text { Full-time Operating } \\
\text { Entity Employees }\end{array}$ & $\begin{array}{l}\text { Part-time Operating } \\
\text { Entity Employees }\end{array}$ & $\begin{array}{c}\text { Total Operating Entity } \\
\text { Employees }\end{array}$ & $\begin{array}{l}2002 \text { Passenger } \\
\text { Boardings }\end{array}$ \\
\hline 1 & Hartsfield-Jackson Atlanta International & 48,000 & 700 & $\begin{array}{c}0 \\
\end{array}$ & \begin{tabular}{|l|}
700 \\
\end{tabular} & $37,720,556$ \\
\hline 2 & Chicago O'Hare International & 45,000 & 1,600 & 0 & 1,600 & $31,706,328$ \\
\hline 3 & Dallas / Fort Worth International & 40,000 & 1,600 & 8 & 1,608 & $24,761,105$ \\
\hline 4 & Miami International & 37,700 & 1,648 & 44 & 1,692 & $14,020,686$ \\
\hline 5 & Los Angeles International & 37,500 & 2,250 & 210 & 2,460 & $26,911,570$ \\
\hline 6 & City of Colorado Springs Municipal & 36,985 & 116 & 2 & 118 & $1,038,027$ \\
\hline 7 & John F. Kennedy International & 35,000 & 800 & 0 & 800 & $14,552,411$ \\
\hline 8 & Phoenix Sky Harbor International & 31,000 & 654 & 3 & 657 & $17,271,519$ \\
\hline 9 & George Bush Intercontinental & 30,000 & 900 & 100 & 1,000 & $15,865,479$ \\
\hline 10 & Denver International & 25,000 & 950 & 0 & 950 & $16,943,564$ \\
\hline 11 & Minneapolis - St Paul International & 25,000 & 532 & 11 & 543 & $15,544,039$ \\
\hline 12 & Lambert - St Louis International & 25,000 & 500 & 0 & 500 & $12,474,566$ \\
\hline 13 & Newark Liberty International & $24,000^{\star \star}$ & * & * & * & $14,553,843$ \\
\hline 14 & San Francisco International & 23,304 & 1,183 & 94 & 1,277 & $14,736,137$ \\
\hline 15 & Philadelphia International & 22,000 & 754 & 28 & 782 & $11,954,469$ \\
\hline 16 & Louisville International - Standiford Field & 20,801 & 171 & 9 & 180 & $1,740,526$ \\
\hline 17 & Memphis International & 20,000 & 300 & 0 & 300 & $5,231,998$ \\
\hline 18 & Seattle - Tacoma International & 19,017 & 723 & 77 & 800 & $12,969,024$ \\
\hline 19 & Washington Dulles International & 18,504 & 554 & 31 & 585 & $7,848,911$ \\
\hline 20 & Detroit Metropolitan Wayne County & 18,171 & 706 & 12 & 718 & $15,525,413$ \\
\hline & TOTALS & 581,982 & 16,641 & 629 & 17,270 & $313,370,171$ \\
\hline
\end{tabular}
**Obtained from http://www.panynj.gov/aviation/ehisfram.htm

Figure 4. Top 20 airports based on total number of reported employees working at airport

\section{Employees by Operating Entity}

The purpose of this section of the article is to discuss the distribution of employees at commercial service airports (CSAs) by their type of operating entity. The reason for this type of analysis is that states, over the years, have subdivided themselves into many different forms of local government entities. In addition to the states, many of these local government entities have become airport operating entities. The survey asked respondents to report their operating entity by the categories shown in Figure 5. Based on the study's $95.1 \%$ response rate, it was determined that cities and airport districts/authorities operated most of the CSAs, $26 \%$ and $25 \%$, respectively, as shown in Figure 6 . The remaining $49 \%$ of the CSAs are operated by various entities such as states, which operate
$18 \%$; counties/parishes/boroughs, which operate $13 \%$; and port districts/authorities, which operate only $7 \%$. "Other" entities operate $11 \%$ of the CSAs, and a detailed listing of these "other" operating entities is listed in Figure 7.

\section{Operating Entity}

City

County

Port District or Authority

Airport District or Authority

State

Other

Figure 5. Operating entities as listed on survey 


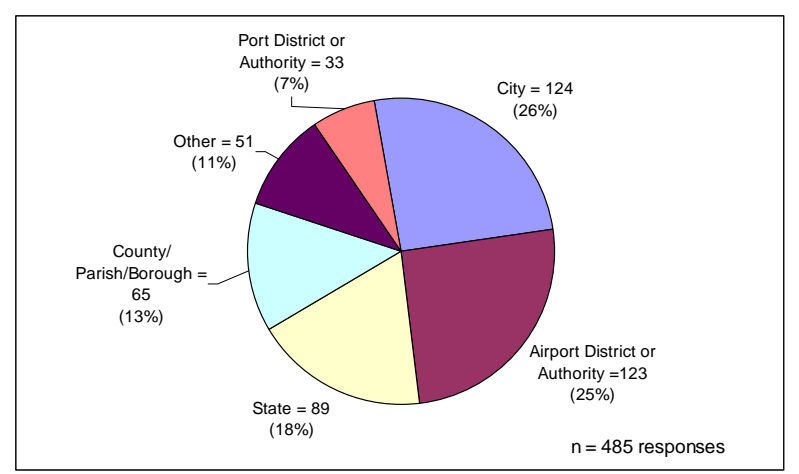

Figure 6. Results by airport operating entity
Of all operating entities, Figure 8 shows that the largest number of total operating entity employees were reported at city airports $(16,116)$ followed by airport authorities/airport districts (13,593). Figure 9 illustrates the average number of employees by airport operating entity type, which shows that an average of 162 employees work at 33 port authority/port district airports while an average of 130 employees work at 124 city airports and an average of 111 employees work at 123 airport authority or district airports.

\begin{tabular}{|c|c|c|c|}
\hline Operating Entity & $\begin{array}{ll}\text { Airports } & \\
\text { Reporting This } \\
\text { Operating } \\
\text { Entity }\end{array}$ & Operating Entity & $\begin{array}{l}\text { Airports } \\
\text { Reporting This } \\
\text { Operating } \\
\text { Entity }\end{array}$ \\
\hline Airport commission & 18 & $\begin{array}{l}\text { Unattached board of the City } \\
\text { of New Orleans }\end{array}$ & 1 \\
\hline Airport board & 5 & Aviation commission & 1 \\
\hline Joint city and county & 5 & Combined city and borough & 1 \\
\hline Private company & 4 & $\begin{array}{l}\text { Unified } \\
\text { government }\end{array}$ & 1 \\
\hline Quasi-private company & 2 & Township & 1 \\
\hline Town & 2 & $\begin{array}{l}\text { Development authority of } \\
\text { former United States Air } \\
\text { Force base }\end{array}$ & 1 \\
\hline University & 2 & $\begin{array}{ll}\text { Economic } & \text { development } \\
\text { corporation }\end{array}$ & 1 \\
\hline $\begin{array}{l}\text { Airport board created by } \\
\text { city/county joint resolution }\end{array}$ & 1 & $\begin{array}{l}\text { Multi-mode transportation } \\
\text { authority }\end{array}$ & 1 \\
\hline $\begin{array}{l}\text { City/county joint powers } \\
\text { board }\end{array}$ & 1 & Park district & 1 \\
\hline Joint powers board & 1 & $\begin{array}{lll}\begin{array}{l}\text { University and } \\
\text { authority }\end{array} & \text { airport } \\
\end{array}$ & 1 \\
\hline \multicolumn{4}{|c|}{ Total 51} \\
\hline
\end{tabular}

Figure 7. "Other" operating entities (as submitted by respondents)

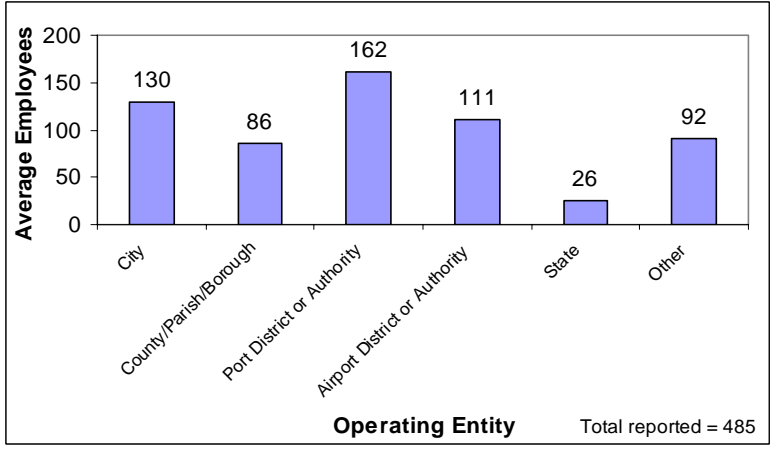

Figure 8. Total (full-time and part-time) operating entity employees

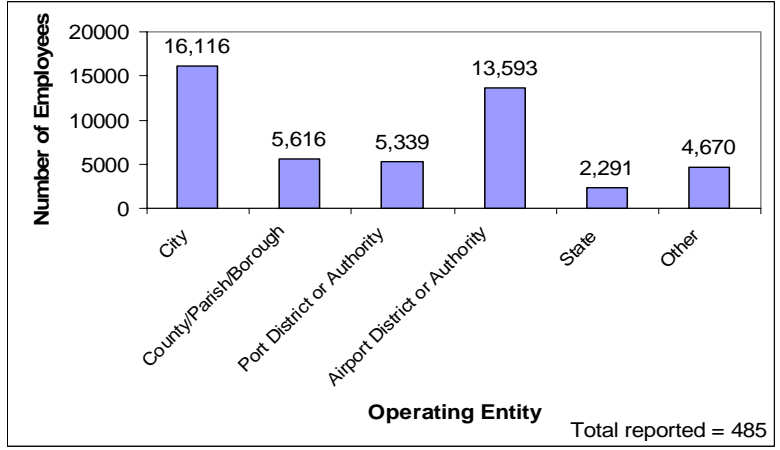

Figure 9. Mean total (full-time and part-time operating entity employment 


\section{Total Number of Employees Working at Airports}

In the survey, respondents were asked for the total number of employees (at the airport) employed by the entity that operates their given airport. As depicted in Figure 10, CSAs run by cities had the highest total number of on-airport employees at 443,228. Airports operated by airport districts or authorities had the second highest total while those CSAs operated by states had the least total on-airport employment.

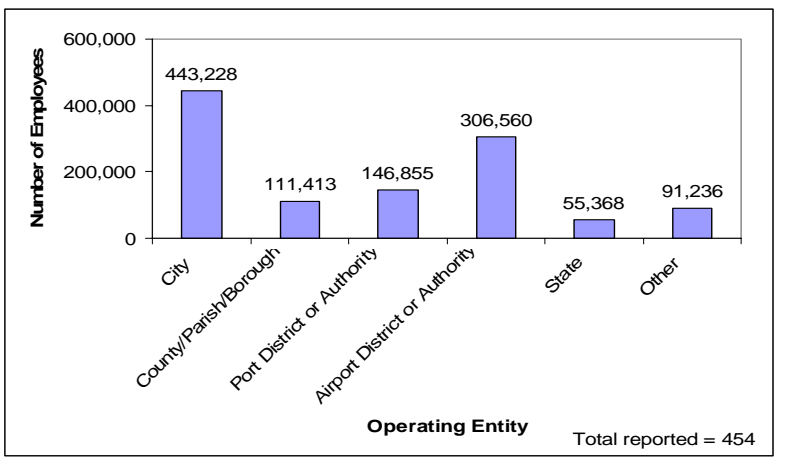

Figure 10. Total reported number of employees working at airport

In an attempt to illustrate how the data might be used to estimate airport employee productivity, Figures 11 (by airport classification) and 12 (by airport enplanement rank) show the average passengers per employee working at the airport while Figures 13 and 14 show the average passengers served per operating entity employee at a given category of CSA, as calculated from the survey results. In these analyses, the employees at the large hub airports or top 50 airports ranked by enplanements cater to considerably more passengers than the airports not in the top 50 CSAs. However, as shown in Figure 11, there is not a large difference in the average passenger departures per total on-airport employee at small hub CSAs versus non-hub CSAs. This is because there was a large number of non-hub CSAs that reported having large numbers of total on-airport employees. For instance, the following non-hub CSAs reported having greater than 1,500 total on-airport employees: St. Petersburg-Clearwater International (PIE), Fort Wayne International (FWA), Lincoln Municipal (LNK), Montgomery Regional (MGM), and
Greater Peoria Regional (PIA).

On the other hand, Figure 12 shows a lower average number of passenger departures per employee in the airports ranked between 51 and 100 compared to those between 101 and 150 . The understatement on the airports ranked between 51 to 100 airports is because some CSAs in this category did not provide their employment figures, and the information was not available to the study through other sources.

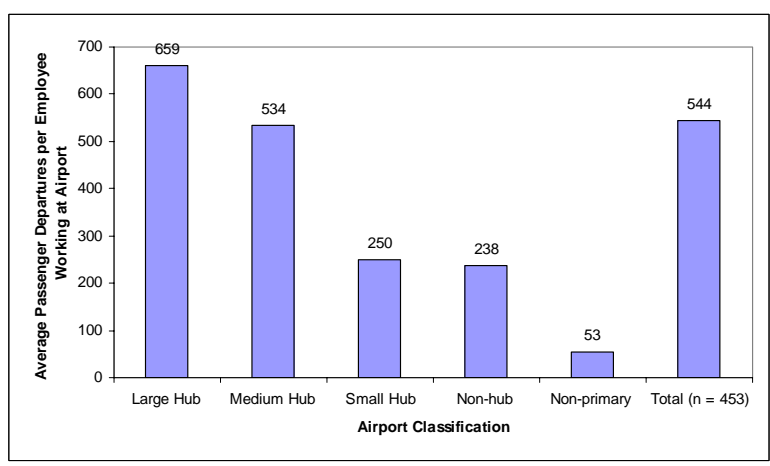

Figure 11. Average passenger departures per employee working at airport (based on airport classification)

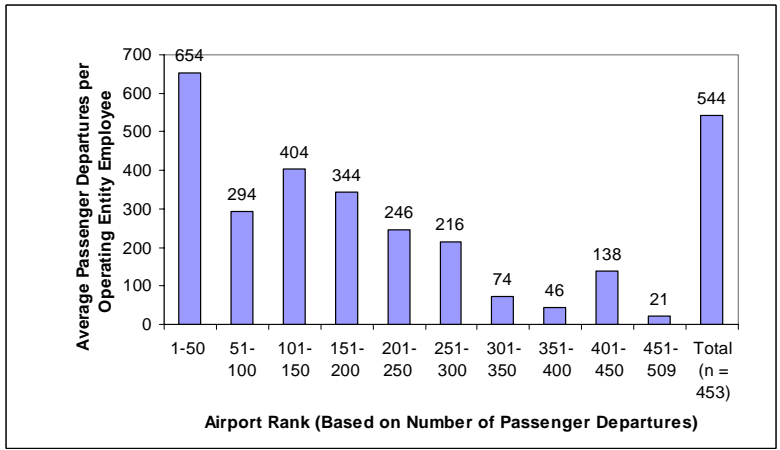

Figure 12. Average passenger departures per employee working at airport (based on enplanement rank)

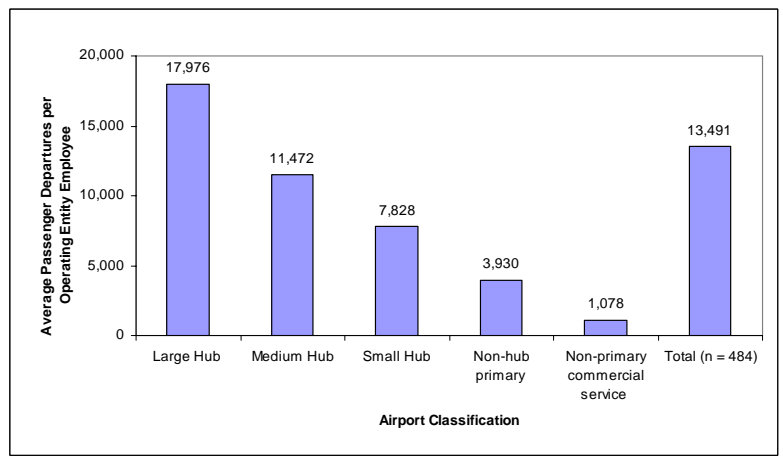

Figure 13. Average passenger departures per operating entity employee (based on airport classification) 


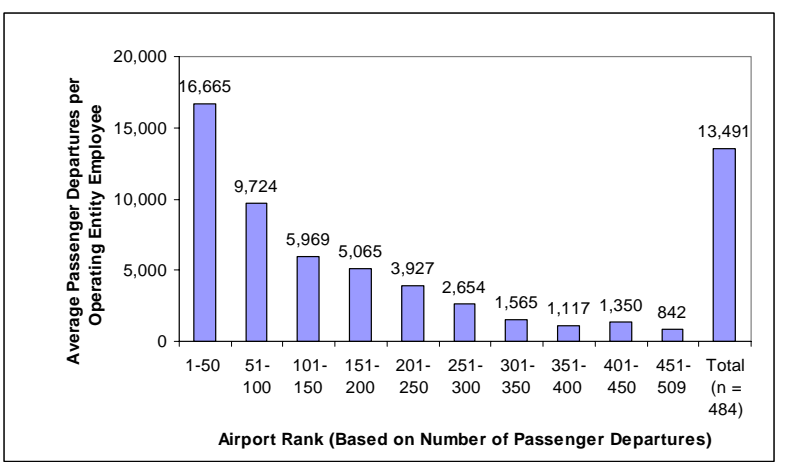

Figure 14. Average passenger departures per operating entity employee based on airport rank)

Furthermore, after obtaining the number of calendar year 2003 aircraft operations, (Airports Council International, Traffic Movements) for the top 10 airports (based on enplanements), a comparison in Figure 15 shows the passengers served per operating entity employee and the number of aircraft operations per operating entity employee. Note that the employment numbers do not have a direct relationship with the airports' operations in regards to enplaned passenger and aircraft operations. However, as shown in Figure 15, both values are illustrated to have identical trends.

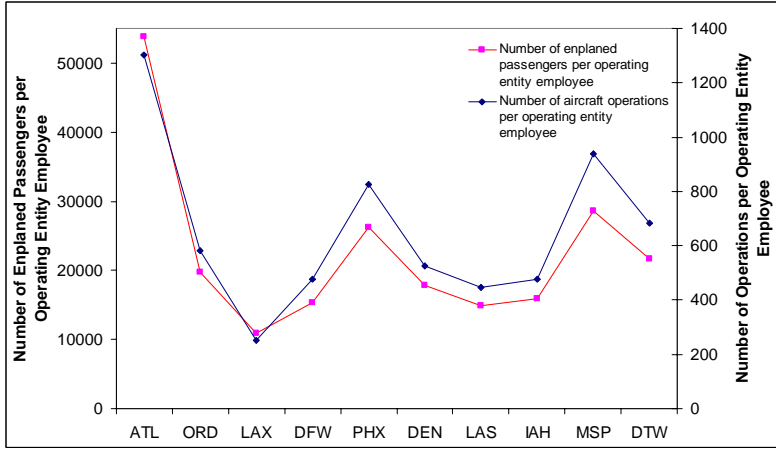

Figure 15. Aircraft operations and enplaned passengers vs. operating entity employees at the top 10 airports

\section{Commercial Service Airport Employment Survey Results Compared to Other Sources}

It should be noted again that the data reported on in this study are self-reported data provided by the airport operating entities. It is assumed that these data are correct since they have been provided by the airport operating entities themselves. However, there is no way to absolutely verify the accuracy of the data reported. This is particularly true of the data reported for "the total number of employees working at the airport (ALL employees, including those employed by airlines, $\mathrm{FBO} / \mathrm{s}$, concessions...." (See Appendix B). These data must be considered estimates and not hard data.

The results obtained from this study can be compared to employment data provided by various sources in literature. First, as stated in the literature review, the US Department of Labor maintains statistics regarding airport operations employees. In 2003, the BLS reported a total of 112,923 employees working at US airports (United States Bureau of Labor Statistics [BLS], Quarterly Census of Employment and Wages). Additionally, the BLS estimated that there were 4,670 people employed as airfield operations specialists in 2003 (BLS, Occupational Employment and Wages, p. 1). The differences between both of the BLS figures and those collected in this study are: (1) the BLS figures include employment at non-CSAs, whereas this study strictly surveyed CSAs, and (2) this study provides data for both operating entity employees $(47,625)$ and total on-airport employees $(1,154,660)$, whereas the BLS numbers do not provide further details of their employment figures. Thus, the current study provides a more detailed account of CSA employment than the BLS.

Moreover, the data collected in this study can be compared to a recent report in Airport Magazine (Page, 2004). As shown in Figures 16 and 17, there are four airport hub classifications-large hub, medium hub, and small hub-for which the average number of operating entity employees was found to be greater in this study than that reported in Airport Magazine. Note that the sample size for the Airport Magazine study was only 188, compared to a more-than-double response rate of 485 in this survey. In addition, this study provides more comprehensive and detailed data, such as employment by type of operating entity, which the Airport Magazine study does not offer. 


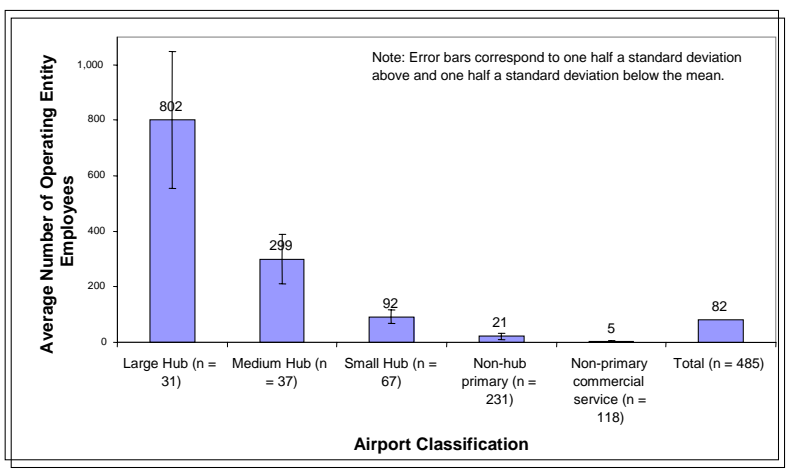

Figure 16. Average number of operating entity employees by airport hub category

Finally, it should be noted that the data collected in this study compares favorably with

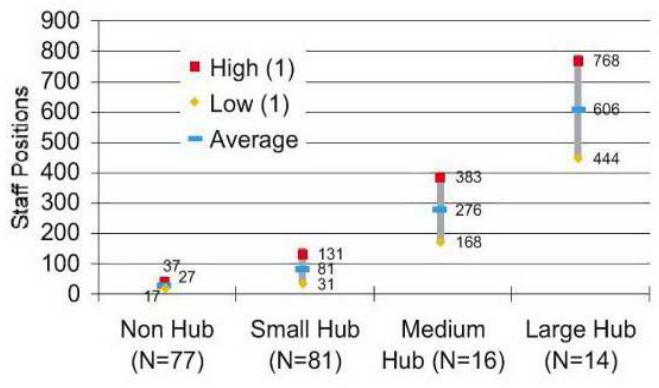

(1) ONE HALF A STANDARD DEVIATION ABOVE (HIGH), OR BELOW (LOW) THE AVERAGE, RESPECTIVELY. Source: Airport Magazine, November/December 2004, p. 24

Figure 17. Average number of operating entity employees as reported in Airport Magazine

Other airport-related employment data reported by the ACI and others:

Operating Entity Employment Overall Employment

\begin{tabular}{l|l|l}
\hline Current Study & $\mathbf{4 7 , 6 2 5}$ & $\mathbf{1 , 1 5 4 , 6 6 0}$ \\
\hline ACI Study for ICAO (2004) & $42,000^{*}$ & $2,000,000^{*}$ \\
\hline ACI Study (2002) & N/A & $1,900,000$ \\
\hline ACI Study (2001) & 43,000 & $1,106,000$ \\
\hline Wilbur Smith Study (1993) & N/A & $2,165,728^{* *}$ \\
\hline
\end{tabular}

*Figures for all of North America

**Figures for all of aviation, not just airports

\section{CONCLUSIONS AND RECOMMENDATIONS}

As is elaborated in the literature review, sources that provide statistics on economic impacts of airports are numerous. Some CSAs have individual economic impact studies, which help to show the significance that CSAs have to regional development. However, a breakdown of the employment at these airports showing employment by airport operating entities is unavailable within these prior airport economic impact studies. However, the current study reported on here provides some specific, selfreported data on airport operating entity employment at the CSAs.

From this study, it can be concluded that:

- there are approximately 47,625 full and part-time employees employed by the entities that operate CSAs in the USA, as reported by the respondents to this survey.
- the top twenty airports (ranked by operating entity employees) employ 20,833 , or $43.7 \%$, of the total.

- the top airport in terms of operating entity employees is LAX with 2,460 employees.

- a total of $1,154,660$ people are employed at CSAs by all on-airport employers (operating entities, airlines, general aviation companies and others). - cities and airport authorities are the most numerous airport operating entities present at CSAs, with 124 and 123 respectively, or $50.9 \%$ of the total reporting.

Further, this study shows that there is a diverse range of operating entities of United States CSAs. Some of the operating entities are defined by regional history; for example, most Alaskan airports are operated by the state because the state attempts to maintain access to various areas of its jurisdiction. Most airports in large cities are operated by the city governments 
as the cities attempt to develop economic gateways in their jurisdiction. There are exceptions to large cities such as New York City, in which its three big airports-Newark Liberty International Airport, La Guardia Airport, and John F. Kennedy International Airport-are run by a port authority. This is because the region's transportation has historically been dependent of the port system.

Most of the total on-airport employment, as well as a large percentage of the operating entity employment, are concentrated at the CSAs that are airline hubs. This mass employment helps to support the United States' hub-and-spoke airport system.

\section{Recommendations}

This study provides a simple methodology for studying employment at United States airports, from which further studies can be conducted at airports other than Commercial Service Airports. In addition, a more complex survey design could be instituted to collect information from multiple sources at the same airport, therefore increasing the overall validity of the results at specific airports. A future study could be conducted to analyze the impact that airport revenues and airport acreage have on airport employment. In doing so, the study could determine whether or not revenues and acreage are good predictors of employment at CSAs. Finally, comprehensive, all-inclusive models for estimating airport employee productivity along the lines of those presented in Airport Magazine could be calibrated using the results of surveys at all categories of airports.

\section{Acknowledgements}

The authors would like to thank the respondents at all of the airports who completed our survey. We especially acknowledge Mr. Carl Siebe of the Alaska Department of Transportation and Public Facilities for providing extensive employment figures at stateoperated Alaskan airports.

We would also like to thank Mr. Rick Lanman at Southern Illinois University Carbondale for his assistance in completing statistical analyses. 


\section{REFERENCES}

Airports Council International. (n.d.). Traffic movements 2003 final. Retrieved April 24, 2005, from http://www.airports.org/cda/aci/display/main/aci_content.jsp?zn=aci\&cp=1-5-54-57-201_9_25

Airports Council International-North America. (2002). The Economic Impact of U.S. Airports. Retrieved April 28, 2005, from http://www.aci-na.org/docs/us_econ_impact.pdf

American Association of Airport Executives. (2003). Membership directory \& yellow pages of corporate members. Alexandria, VA: Author.

Arizona Department of Transportation Aeronautics Division. (2004, May). Economic impact of aviation in Arizona. Retrieved April 17, 2005, from http://www.dot.state.az.us/aviation/ development/PDF/Economic_Impact_of_Aviation_in_AZ_02-03.pdf

Colorado Department of Transportation Aeronautics Division. (2003). The economic impacts of airports in Colorado. (Available from Colorado Department of Transportation, Division of Aeronautics, 5126 Front Range Parkway, Watkins, CO 80137).

Dri-Wefa, Inc. (2002, July). The national economic impact of civil aviation. Retrieved January 19, 2005, from www.gama.aero/dloads/DRI-WEFA_EconomicImpactStudy.pdf

Federal Aviation Administration. (n.d.). "Passenger boardings, rank order, and percentage change from 2002, commercial service airports only." Retrieved September 15, 2004, from http://www.faa.gov/arp/planning/stats/2002/CY02CommSerBoard.xls

Federal Aviation Administration. (n.d.). Report to Congress - National plan of integrated airport systems (2005-2009). Retrieved March 29, 2005, from http://www.faa.gov/arp/planning/ npias/npias2005/NPIAS2005Narr.pdf

Gallatin Field airport fact sheet. (2004). Retrieved April 25, 2005, from http://www.gallatinfield.com/pub/charts/Gallatin\%20Field\%20Airport\%20-20Fact\%20Sheet.pdf

General information about Lambert. (n.d.). Retrieved November 12, 2004, from http://www.lambertstlouis.com/about/index.htm

General statistics BWI fast facts. (n.d.). Retrieved April 25, 2005, from http://www.bwiairport.com/ about_bwi/general_statistics/

Georgia Department of Transportation. (n.d.). Fact book 2004. Retrieved April 17, 2005, from http://www.dot.state.ga.us/dot/communications/publications/documents/pdf/factbook/factbook2004.pdf

Harrah, J., Gallagher, A., \& Townsend, M. (2003, November). Wichita Mid-Continent Airport economic impact. Retrieved February 2, 2005, from http://webs.wichita.edu/depttools/ depttoolsmemberfiles/cedbr/AirportImpact.pdf

Hartgen, D. T., Bondurant, J. D., Dakai, W. C., Morris, B. J., \& Stuart, A. W. (1997, May).Factors affecting commercial and general aviation airport activity in North Carolina (Trans. Pub. No. 160). Charlotte, North Carolina: University of North Carolina, Department of Geography and Earth Science. 
International Civil Aviation Organization. (2004, September). Airports: Vital catalyst for economic growth (Working Paper No. A35-WP/199). Retrieved April 29, 2005, from http://www.icao.int/ icao/en/assembl/a35/wp/wp199_en.pdf

Jackman, F. (Ed.). (2004, Winter). World Aviation Directory \& Aerospace Database (2nd ed.). New York: McGraw Hill.

Jamison, A. (1996, September). The economic impact of Illinois airports. (Available from the Illinois Department of Transportation, Division of Aeronautics, One Langhorne Bond Drive, Capital Airport, Springfield, IL 62707).

Missouri Department of Transportation. (n.d.). The economic benefit of Missouri's airport system. (Available from Missouri Department of Transportation Aviation Section, P.O. Box 270, Jefferson City, MO 65102).

New Mexico Department of Transportation Aviation Division. (2003). 2003 Economic impact of aviation in New Mexico. Retrieved April 10, 2005, from http://www.nmshtd.state.nm.us/ upload/ images/Aviation/Economic-Impact-2003.pdf

NewMyer, D. A., Kaps, R., \& Sharp, S. E. (1997, Spring). Aviation employment data estimates revisited. Journal of Aviation/Aerospace Education and Research, 7(3), 7-17.

NewMyer, D. A., \& Owen, R. T. C. (2003, October). Aviation employment in the US: A review of data sources. Collegiate Aviation Review, 21(1), 46-59.

Page, S. N. (2004, November/December). Do you have enough staff? An update (Part 1 of 2). Airport Magazine, 24-25.

Page, S. N. (2005, January/February). Do you have enough staff? An update (Part 2 of 2). Airport Magazine, 18-19.

Port Authority of New York and New Jersey. (n.d.). Newark Liberty facts. Retrieved November 12, 2004, from http://www.panynj.gov/aviation/ehisfram.htm

San Jose International Airport. (1986). 1986 Economic impact report summary. Retrieved December 17, 2004, from http://www.aaae.org/members/240_Library/

Swenson, D., \& Eathington, L. (2000, August). The economic values of Iowa's air transportation industries. Retrieved April 17, 2005, from http://www.iawings.com/pdfs/av_econ_impact.pdf

Texas Department of Transportation. (n.d.). Economic impact of general aviation in Texas. Retrieved April 10, 2005, from http://www.dot.state.tx.us/avn/econimp/TxAptSum/pdf

That was then... (2001, December/January). Airport World, 6(6), 42-43.

United States Bureau of Labor Statistics. (n.d.) Occupational employment and wages, November 2003, 53-2022 airfield operations specialists. Retrieved March 2, 2005, from http://www.bls.gov/ oes/current/oes532022.htm

United States Bureau of Labor Statistics. (n.d.) Quarterly census of employment and wages-NAICS Code 48811. Retrieved March 2, 2005, from http://data.bls.gov/PDQ/outside.jsp?survey=en 
United States Department of Transportation, Bureau of Transportation Statistics (n. d.), Enplanments at Commercial Service Airports, By Carrier Type (Source: CY 2003 ACAIS), Retrieved August 3, 2005 from http://www.faa.gov/arp/planning/stats/2003/Cy03CMArptsbyTypeofCarrier.pdf

United States Census Bureau. (n.d.). 48811 Airport operations. Retrieved April 28, 2005, from http://www.census.gov/econ/census02/naics/sector48/48811.htm

Vermont Agency of Transportation. (n.d.). Vermont. Retrieved April 7, 2005, from http://www.aot.state.vt.us/Documents/aeis.pdf

Washington State Department of Transportation Aviation Division. (n.d.). Economic impacts of Washington airports. Retrieved April 7, 2005, from http://www.wsdot.wa.gov/aviation/ EconImpacts/EconomicAnalysisReport.pdf

Wilbur Smith Associates. (1995, April). The economic impact of civil aviation on the U.S. economy. Retrieved April 26, 2005, from http://www.aaae.org/members/240_Library/

Wilbur Smith Associates. (2000, August). Technical summary for the Florida airports economic impact study. Retrieved April 7, 2005, from http://www.dot.state.fl.us/aviation/pdfs/economic.pdf 


\section{APPENDIX A}

\section{Airport Employment Survey}

The purpose of this research is to update a study of aviation employment that was completed in 2003. One aspect of the research is to obtain an estimate of employment at commercial service airports in the USA. If you wish your airport's employment numbers to remain confidential, please inform us so that we may protect that confidentiality. In any case, Southern Illinois University Carbondale will not publish the names of those contacted for this survey.

1. Job title of person completing survey:

2. Airport name and associated city:

3. What is the operating entity of the airport?
A. City
B. County
C. Port District or Authority
D. Airport District or Authority
E. State
F. Other, please specify:

4. What is the total number of employees (at the airport) employed by the entity that operates the airport?

Full-time employees:

Part-time employees:

5. What is the total number of employees working at the airport (ALL employees, including those employed by airlines, FBOs, concessions, etc.)?

6. Comments:

Dr. David A. NewMyer

Professor and Chair

Department of Aviation Management and Flight

Southern Illinois University Carbondale

College of Applied Sciences and Arts

Mailcode 6623

Carbondale, IL 62901-6623

Phone: 618/453-8898

Fax: 618/453-7286

newmyer@siu.edu 


\section{APPENDIX B}

Additional Results - Operating Entity Analyses

Table B1. Top 20 airports ranked by enplanements

\begin{tabular}{|c|c|c|c|c|c|c|c|}
\hline & Airport Name & $\begin{array}{l}2002 \text { Passenger } \\
\text { Boardings }\end{array}$ & Operating Entity & $\begin{array}{c}\text { Full-time } \\
\text { Operating Entity } \\
\text { Employees }\end{array}$ & $\begin{array}{c}\text { Part-time } \\
\text { Operating Entity } \\
\text { Employees }\end{array}$ & \begin{tabular}{|c|} 
Total Operating \\
Entity \\
Employees
\end{tabular} & $\begin{array}{c}\text { Total Reported } \\
\text { Employees Working } \\
\text { at Airport }\end{array}$ \\
\hline 1 & Hartsfield-Jackson Atlanta International & $37,720,556$ & City & 700 & 0 & 700 & \begin{tabular}{|c|}
48,000 \\
\end{tabular} \\
\hline 2 & Chicago O'Hare International & $31,706,328$ & City & 1,600 & 0 & 1,600 & 45,000 \\
\hline 3 & Los Angeles International & $26,911,570$ & City & 2,250 & 210 & 2,460 & 37,500 \\
\hline 4 & Dallas / Fort Worth International & $24,761,105$ & Airport District or Authority & 1,600 & 8 & 1,608 & 40,000 \\
\hline 5 & Phoenix Sky Harbor International & $17,271,519$ & City & 654 & 3 & 657 & 31,000 \\
\hline 6 & Denver International & $16,943,564$ & City & 950 & 0 & 950 & 25,000 \\
\hline 7 & McCarran International & $16,600,807$ & County & 1,100 & 20 & 1,120 & 15,120 \\
\hline 8 & George Bush Intercontinental & $15,865,479$ & City & 900 & 100 & 1,000 & 30,000 \\
\hline 9 & Minneapolis - St Paul International & $15,544,039$ & Other: Airport commission & 532 & 11 & 543 & 25,000 \\
\hline 10 & Detroit Metropolitan Wayne County & $15,525,413$ & Airport District or Authority & 706 & 12 & 718 & 18,171 \\
\hline 11 & San Francisco International & $14,736,137$ & Other: Airport commission & 1,183 & 94 & 1,277 & 23,304 \\
\hline 12 & Newark Liberty International & $14,553,843$ & Port District or Authority & * & * & * & $24,000^{* *}$ \\
\hline 13 & John F. Kennedy International & $14,552,411$ & Port District or Authority & 800 & 0 & 800 & 35,000 \\
\hline 14 & Miami International & $14,020,686$ & County & 1,648 & 44 & 1,692 & 37,700 \\
\hline 15 & Seattle - Tacoma International & $12,969,024$ & Port District or Authority & 723 & 77 & 800 & 19,017 \\
\hline 16 & Orlando International & $12,921,480$ & Airport District or Authority & 618 & 47 & 665 & 16,600 \\
\hline 17 & Lambert - St Louis International & $12,474,566$ & City & 500 & 0 & 500 & 25,000 \\
\hline 18 & Philadelphia International & $11,954,469$ & City & 754 & 28 & 782 & 22,000 \\
\hline 19 & Charlotte / Douglas International & $11,743,157$ & City & 230 & 120 & 350 & 15,694 \\
\hline 20 & General Edward Lawrence Logan International & $11,077,238$ & Port District or Authority & 1,093 & 31 & 1,124 & 15,000 \\
\hline & TOTALS & $349,853,391$ & & 18,541 & 805 & 19,346 & 548,106 \\
\hline
\end{tabular}

**Obtained from http://www.panynj.gov/aviation/ehisfram.htm

Table B2. Top 20 city-operated airports ranked by enplanements

\begin{tabular}{|c|c|c|c|c|c|c|}
\hline & Airport Name & $\begin{array}{c}2002 \text { Passenger } \\
\text { Boardings }\end{array}$ & $\begin{array}{c}\text { Full-time Operating Entity } \\
\text { Employees }\end{array}$ & $\begin{array}{c}\text { Part-time Operating Entity } \\
\text { Employees }\end{array}$ & $\begin{array}{c}\text { Total Operating Entity } \\
\text { Employees }\end{array}$ & $\begin{array}{c}\text { Total Reported Employees } \\
\text { Working at Airport }\end{array}$ \\
\hline 1 & Hartsfield-Jackson Atlanta International & $37,720,556$ & 700 & \begin{tabular}{|c|}
0 \\
\end{tabular} & 700 & \begin{tabular}{|c|}
48,000 \\
\end{tabular} \\
\hline 2 & Chicago O'Hare International & $31,706,328$ & 1,600 & 0 & 1,600 & 45,000 \\
\hline 3 & Los Angeles International & $26,911,570$ & 2,250 & 210 & 2,460 & 37,500 \\
\hline 4 & Phoenix Sky Harbor International & $17,271,519$ & 654 & 3 & 657 & 31,000 \\
\hline 5 & Denver International & $16,943,564$ & 950 & 0 & 950 & 25,000 \\
\hline 6 & George Bush Intercontinental & $15,865,479$ & 900 & 100 & 1,000 & 30,000 \\
\hline 7 & Lambert - St Louis International & $12,474,566$ & 500 & 0 & 500 & 25,000 \\
\hline 8 & \begin{tabular}{|l|l|} 
Philadelphia International \\
\end{tabular} & $11,954,469$ & 754 & 28 & 782 & 22,000 \\
\hline 9 & Charlotte / Douglas International & $11,743,157$ & 230 & 120 & 350 & 15,694 \\
\hline 10 & Salt Lake City International & $8,997,942$ & 576 & 8 & 584 & 14,000 \\
\hline 11 & Chicago Midway International & $7,878,438$ & 207 & 0 & 207 & 9,915 \\
\hline 12 & Norman Y. Mineta San Jose International & $5,248,193$ & 388 & 5 & 393 & 6,707 \\
\hline 13 & Kansas City International & $5,161,518$ & 422 & 6 & 428 & 5,700 \\
\hline 14 & Cleveland - Hopkins International & $5,146,975$ & 450 & 0 & 450 & 10,000 \\
\hline 15 & William P. Hobby & $3,819,306$ & 237 & 0 & 237 & 5,907 \\
\hline 16 & San Antonio International & $3,224,764$ & 420 & 1 & 421 & Unknown \\
\hline 17 & Austin - Bergstrom International & $3,186,381$ & 375 & $\frac{1}{15}$ & 390 & 3,600 \\
\hline 18 & Ontario International & $3,092,677$ & 390 & 18 & 408 & 5,000 \\
\hline 19 & Albuquerque International Sunport & $2,973,093$ & 260 & 5 & 265 & 3,400 \\
\hline 20 & Dallas Love Field & $2,815,907$ & 152 & 1 & 153 & 8,558 \\
\hline & TOTALS & $234,136,402$ & 12,415 & 520 & 12,935 & 351,981 \\
\hline
\end{tabular}

Table B3. Top 20 airport district or airport authority-operated airports ranked by enplanements

\begin{tabular}{|c|c|c|c|c|c|c|}
\hline & Airport Name & $\begin{array}{l}2002 \text { Passenger } \\
\text { Boardings }\end{array}$ & $\begin{array}{c}\text { Full-time Operating Entity } \\
\text { Employees }\end{array}$ & $\begin{array}{c}\text { Part-time Operating Entity } \\
\text { Employees }\end{array}$ & $\begin{array}{c}\text { Total Operating Entity } \\
\text { Employees }\end{array}$ & $\begin{array}{c}\text { Total Reported Employees } \\
\text { Working at Airport }\end{array}$ \\
\hline 1 & Dallas / Fort Worth International & $24,761,105$ & 1,600 & \begin{tabular}{|c|}
8 \\
\end{tabular} & 1,608 & 40,000 \\
\hline 2 & Detroit Metropolitan Wayne County & $15,525,413$ & 706 & 12 & 718 & 18,171 \\
\hline 3 & Orlando International & $12,921,480$ & 618 & 47 & 665 & 16,600 \\
\hline 4 & Cincinnati /Northern Kentucky International & $10,316,170$ & 366 & 53 & 419 & 15,000 \\
\hline 5 & Pittsburgh International & $8,975,111$ & 360 & 0 & 360 & 9,000 \\
\hline 6 & Washington Dulles International & $7,848,911$ & 554 & 31 & 585 & 18,504 \\
\hline 7 & Tampa International & $7,726,576$ & 564 & 0 & 564 & 7,000 \\
\hline 8 & San Diego International & $7,392,389$ & 273 & 1 & 274 & 5,000 \\
\hline 9 & Ronald Reagan Washington National & $6,172,065$ & 1,116 & 31 & 1,147 & 9,735 \\
\hline 10 & Memphis International & $5,231,998$ & 300 & 0 & 300 & 20,000 \\
\hline 11 & Raleigh - Durham International & $4,198,873$ & 245 & 0 & 245 & 4,500 \\
\hline 12 & Nashville International & $4,009,959$ & 398 & 15 & 413 & 3,113 \\
\hline 13 & Port Columbus International & $3,283,639$ & 350 & 20 & 370 & 5,000 \\
\hline 14 & Southwest Florida International & $2,551,187$ & 285 & 3 & 288 & 3,500 \\
\hline 15 & Jacksonville International & $2,462,399$ & 240 & 20 & 260 & 4,000 \\
\hline 16 & Burbank - Glendale - Pasadena & $2,305,747$ & 258 & 42 & 300 & 1,395 \\
\hline 17 & Reno / Tahoe International & $2,170,828$ & 218 & 11 & 229 & 2,900 \\
\hline 18 & Eppley Airfield & $1,747,320$ & 123 & 14 & 137 & 1,140 \\
\hline 19 & Louisville International - Standiford Field & $1,740,526$ & 171 & 9 & 180 & 20,801 \\
\hline 20 & Norfolk International & $1,731,105$ & 200 & 4 & 204 & 2,000 \\
\hline & TOTALS & $133,072,801$ & 8,945 & 321 & 9,266 & 207,359 \\
\hline
\end{tabular}


Table B4. Top 20 county-operated airports ranked by enplanements

\begin{tabular}{|c|c|c|c|c|c|c|}
\hline & Airport Name & $\begin{array}{l}2002 \text { Passenger } \\
\text { Boardings }\end{array}$ & $\begin{array}{c}\text { Full-time Operating Entity } \\
\text { Employees }\end{array}$ & $\begin{array}{c}\text { Part-time Operating Entity } \\
\text { Employees }\end{array}$ & $\begin{array}{l}\text { Total Operating Entity } \\
\text { Employees }\end{array}$ & $\begin{array}{l}\text { Total Reported Employees } \\
\text { Working at Airport }\end{array}$ \\
\hline 1 & McCarran International & $16,600,807$ & 1,100 & 20 & 1,120 & 15,120 \\
\hline 2 & Miami International & $14,020,686$ & 1,648 & 44 & 1,692 & 37,700 \\
\hline 3 & Fort Lauderdale / Hollywood International & $8,266,788$ & 400 & 12 & 412 & 10,500 \\
\hline 4 & Sacramento International & $4,260,514$ & 434 & 0 & 434 & 3,915 \\
\hline 5 & John Wayne - Orange County & $3,968,978$ & 138 & 0 & 138 & 4,000 \\
\hline 6 & General Mitchell International & $2,779,197$ & 200 & 0 & 200 & 6,500 \\
\hline 7 & \begin{tabular}{|l|l|} 
Palm Beach International \\
\end{tabular} & $2,716,514$ & 145 & 0 & 145 & 3,681 \\
\hline 8 & Greater Rochester International & $1,176,736$ & 100 & 1 & 101 & 2,000 \\
\hline 9 & Gerald R. Ford International & 960,482 & 114 & 20 & 134 & 1,680 \\
\hline 10 & Dane County Regional - Truax Field & 759,506 & 60 & 6 & 66 & 6,500 \\
\hline 11 & Myrtle Beach International & 614,828 & 103 & 0 & 103 & 500 \\
\hline 12 & Westchester County & 461,448 & 50 & 3 & 53 & 1,400 \\
\hline 13 & Austin Straubel International & 359,230 & 24 & 0 & 24 & 400 \\
\hline 14 & Eglin AFB & 324,962 & 32 & 0 & 32 & Unknown \\
\hline 15 & St Petersburg - Clearwater International & 310,650 & 61 & 0 & 61 & 1,648 \\
\hline 16 & Key West International & 272,440 & 23 & 1 & 24 & 500 \\
\hline 17 & Outagamie County Regional & 259,624 & 25 & 2 & 27 & 1,200 \\
\hline 18 & Daytona Beach International & 234,558 & 40 & 0 & 40 & 700 \\
\hline 19 & Kalamazoo / Battle Creek International & 233,554 & 13 & 1 & 14 & 200 \\
\hline 20 & Rogue Valley International - Medford & 219,569 & 35 & 15 & 50 & 1,000 \\
\hline & TOTALS & $58,801,071$ & 4,745 & 125 & 4,870 & 99,144 \\
\hline
\end{tabular}

Table B5. Top 20 port district or port authority-operated airports ranked by enplanements

\begin{tabular}{|c|c|c|c|c|c|c|}
\hline & Airport Name & $\begin{array}{l}2002 \text { Passenger } \\
\text { Boardings }\end{array}$ & $\begin{array}{c}\text { Full-time Operating Entity } \\
\text { Employees }\end{array}$ & $\begin{array}{c}\text { Part-time Operating Entity } \\
\text { Employees }\end{array}$ & $\begin{array}{c}\text { Total Operating Entity } \\
\text { Employees }\end{array}$ & $\begin{array}{c}\text { Total Reported Employees } \\
\text { Working at Airport }\end{array}$ \\
\hline 1 & Newark Liberty International & $14,553,843$ & $*$ & $*$ & * & $24,000^{* *}$ \\
\hline 2 & John F. Kennedy International & $14,552,411$ & 800 & 0 & 800 & 35,000 \\
\hline 3 & Seattle - Tacoma International & $12,969,024$ & 723 & 77 & 800 & 19,017 \\
\hline 4 & General Edward Lawrence Logan International & $11,077,238$ & 1,093 & 31 & 1,124 & 15,000 \\
\hline 5 & La Guardia & $11,076,032$ & 500 & 0 & 500 & 9,000 \\
\hline 6 & Metropolitan Oakland International & $6,164,548$ & 265 & 6 & 271 & 8,000 \\
\hline 7 & Portland International & $5,978,025$ & 280 & 27 & 307 & 8,963 \\
\hline 8 & Luis Munoz Marin International & $4,607,290$ & 285 & 0 & 285 & 16,912 \\
\hline 9 & Orlando Sanford & 648,144 & 65 & 10 & 75 & 4,000 \\
\hline 10 & Saipan International & 513,734 & 195 & 0 & 195 & 720 \\
\hline 11 & Cyril E King & 512,986 & 44 & 0 & 44 & 80 \\
\hline 12 & Toledo Express & 323,988 & 67 & 3 & 70 & 4,000 \\
\hline 13 & Tri - Cities & 211,473 & 36 & 10 & 46 & 596 \\
\hline 14 & Henry E Rohlsen & 179,581 & 37 & 0 & 37 & Unknown \\
\hline 15 & Craven County Regional & 74,884 & 5 & 36 & 41 & 77 \\
\hline 16 & Bellingham International & 70,517 & 14 & 0 & 14 & 149 \\
\hline 17 & Pangborn Memorial & 41,858 & 8 & 0 & 8 & 50 \\
\hline 18 & Worcester Regional & 37,298 & 22 & 1 & 23 & 46 \\
\hline 19 & Williamsport Regional & 32,883 & 8 & 14 & 22 & 450 \\
\hline 20 & Walla Walla Regional & 28,076 & 11 & 3 & 14 & 56 \\
\hline & TOTALS & $83,653,833$ & 4,458 & 218 & 4,676 & 146,116 \\
\hline
\end{tabular}

**Obtained from http://www.panynj.gov/aviation/ehisfram.htm

Table B6. Top 20 state-operated airports ranked by enplanements

\begin{tabular}{|c|c|c|c|c|c|c|}
\hline & Airport Name & $\begin{array}{l}2002 \text { Passenger } \\
\text { Boardings }\end{array}$ & $\begin{array}{c}\text { Full-time Operating Entity } \\
\text { Employees }\end{array}$ & $\begin{array}{c}\text { Part-time Operating Entity } \\
\text { Employees }\end{array}$ & $\begin{array}{l}\text { Total Operating Entity } \\
\text { Employees }\end{array}$ & $\begin{array}{c}\text { Total Reported Employees } \\
\text { Working at Airport }\end{array}$ \\
\hline 1 & Honolulu International & $9,406,467$ & 550 & 0 & 550 & \begin{tabular}{|c|}
17,000 \\
\end{tabular} \\
\hline 2 & Baltimore - Washington International & $9,367,499$ & 542 & 0 & 542 & 15,100 \\
\hline 3 & Bradley International & $3,221,081$ & 100 & 0 & 100 & 4,500 \\
\hline 4 & Kahului & $2,663,824$ & 116 & 4 & 120 & Unknown \\
\hline 5 & Ted Stevens Anchorage International & $2,388,563$ & 350 & 22 & 372 & 12,000 \\
\hline 6 & Lihue & $1,238,972$ & 100 & 0 & 100 & Unknown \\
\hline 7 & Kona International at Keahole & $1,200,897$ & 77 & 0 & 77 & 2,494 \\
\hline 8 & Hilo International & 712,162 & * & * & * & Unknown \\
\hline 9 & Fairbanks International & 380,576 & 96 & 4 & 100 & 1,600 \\
\hline 10 & Grand Canyon National Park & 337,189 & 15 & 0 & 15 & 325 \\
\hline 11 & Bethel & 132,057 & 9 & 0 & 9 & 159 \\
\hline 12 & University of Illinois - Willard & 117,503 & 26 & 7 & 33 & 357 \\
\hline 13 & Molokai & 93,307 & 12 & 0 & 12 & Unknown \\
\hline 14 & Sitka Rocky Gutierrez & 70,095 & 9 & 0 & 9 & 44 \\
\hline 15 & Lanai & 64,583 & 9 & 1 & 10 & Unknown \\
\hline 16 & Kodiak & 62,862 & 5 & 0 & 5 & 30 \\
\hline 17 & Ralph Wien Memorial & 52,106 & 5 & 0 & 5 & 40 \\
\hline 18 & Nome & 49,602 & 8 & 0 & 8 & 43 \\
\hline 19 & King Salmon & 35,882 & 6 & 0 & 6 & 31 \\
\hline 20 & Dillingham & 34,746 & 6 & 0 & 6 & 51 \\
\hline & TOTALS & $31,629,973$ & 2,041 & 38 & 2,079 & 53,774 \\
\hline
\end{tabular}

